\title{
Plasma membrane expression of GnRH receptors: regulation by antagonists in breast, prostate, and gonadotrope cell lines
}

\author{
Ann R Finch, Kathleen R Sedgley, Christopher J Caunt and Craig A McArdle \\ Laboratories for Integrative Neuroscience and Endocrinology, University of Bristol, Dorothy Hodgkin Building, Whitson Street, Bristol BS1 3NY, UK \\ (Correspondence should be addressed to C A McArdle; Email: craig.mcardle@bris.ac.uk)
}

\begin{abstract}
In heterologous expression systems, human $\mathrm{GnRH}$ receptors (hGnRHRs) are poorly expressed at the cell surface and this may reflect inefficient exit from the endoplasmic reticulum. Here, we have defined the proportion of GnRHRs at the cell surface using a novel assay based on adenoviral transduction with epitopetagged GnRHRs followed by staining and semi-automated imaging. We find that in MCF7 (breast cancer) cells, the proportional cell surface expression (PCSE) of hGnRHRs is remarkably low $(<1 \%)$, when compared with Xenopus laevis $(\mathrm{X})$ GnRHRs ( 40\%). This distinction is retained at comparable whole cell expression levels, and the hGnRHR PCSE is increased by addition of the XGnRHR C-tail (h.XGnRHR) or by a membrane-permeant pharmacological chaperone (IN3). The IN3 effect is concentration- and time-dependent and IN3 also enhances the hGnRHR-mediated (but not
\end{abstract}

h.XGnRHR- or mouse GnRHR-mediated) stimulation of $\left[{ }^{3} \mathrm{H}\right]$ inositol phosphate accumulation and the hGnRHRmediated reduction in cell number. We also find that the PCSE for hGnRHRs and h.XGnRHRs is low and is greatly increased by IN3 in two hormone-dependent cancer lines, but is higher and less sensitive to IN3 in a gonadotrope line. Finally, we show that the effect of IN3 on hGnRHR PCSE is not mimicked or blocked by two peptide antagonists although they do increase the PCSE for h.XGnRHRs, revealing that an antagonistoccupied cell surface GnRHR conformation can differ from that of the unoccupied receptor. The low PCSE of hGnRHRs and this novel peptide antagonist effect may be important for understanding GnRHR function in extrapituitary sites.

Journal of Endocrinology (2008) 196, 353-367

\section{Introduction}

Genetic disease can result from mutations that impair protein trafficking by causing misfolding and failure to meet quality control for exit of newly synthesized protein from the endoplasmic reticulum (ER; Kopito \& Ron 2000). One of the key advances in this field has been the development of pharmacological chaperones that stabilize protein conformations that are more efficiently trafficked. In the case of seven transmembrane (7TM) receptors, at least ten diseases are linked to mutations within the receptor that cause retention in the ER. For at least three of these receptors, pharmacological chaperones have been found that may increase ER exit and thereby increase trafficking to the plasma membrane (PM; Bernier et al. 2004). There is also increasing evidence that a large proportion of normal (non-mutated) proteins also fail to exit the ER. Indeed, it appears that only $40 \%$ of newly synthesized human Sopioid receptor is actually transported to the PM in human embryonic kindney (HEK)-293 cells (Petaja-Repo et al. 2002). The receptors that fail to exit the ER are instead ubiquitinated and targeted to the proteosome, while membrane-permeant ligands (agonists and antagonists) increase the proportion of receptors trafficked to the PM (Petaja-Repo et al. 2002). Accordingly, there is considerable interest in the possibility that pharmacological chaperones may have therapeutic benefit in manipulation of wild-type 7TM receptors, as well as in treatment of congenital diseases of 7TM receptor trafficking.

Gonadotropin-releasing hormone I (pGlu-His-Trp-SerTyr-Gly-Leu-Arg-Pro-Gly-NH2, GnRH-I) acts via $\mathrm{G}_{\alpha \mathrm{q}^{-}}$ coupled 7TM receptors to stimulate phospholipase C (PLC). The consequent mobilization of $\mathrm{Ca}^{2+}$ and activation of protein kinase $\mathrm{C}$ isozymes mediates secretion of luteinizing hormone and follicle-stimulating hormone (Conn et al. 1987, Stojilkovic \& Catt 1995, Millar et al. 2004). Most vertebrates express GnRH II $\left(\left[\mathrm{His}^{5}, \operatorname{Trp}^{7}, \mathrm{Tyr}^{8}\right] \mathrm{GnRH}\right)$ along with one or more related peptide. These forms of GnRH have apparently evolved in parallel with distinct forms of the GnRHR (Millar et al. 2004). The best-characterized GnRHRs (mammalian type I GnRHRs) are selective for GnRH I. They include all known mammalian GnRHRs except for the type II GnRHRs recently described in some primates and, unlike all other 7TM receptors, lack C-terminal tails. In contrast, non-mammalian GnRHRs have higher affinity for GnRH II than for GnRH I and have C-tails of varying length (Millar et al. 2004). These structures are thought to be involved in receptor desensitization and internalization (Pawson et al. 1998, Blomenrohr et al. 1999, McArdle et al. 2002, Millar et al. 2004) and may also influence receptor expression (below). 
Although the proportion of GnRHRs reaching the PM is unknown, cell surface human (h)GnRHR expression is typically low in heterologous systems (compared with other GnRHRs) due to specific structural features. For example, a primate GnRHR-specific Lys191 may reduce GnRHRs expression by destabilizing a cysteine bridge that is needed for ER exit (Janovick et al. 2003, Ulloa-Aguirre et al. 2004, Sedgley et al. 2006). Glycosylation can also influence expression because the mouse GnRHR has glycosylation sites at Asn 4 and Asn 18 within the amino-terminal sequence and is expressed at higher levels than hGnRHR (which has only the Asn18 site). hGnRHR expression is increased by adding a second glycosylation site (Asn4), just as mGnRHR expression is reduced by removal of Asn18 (Davidson et al. 1995, 1996, Sedgley et al. 2006). The absence or the presence of C-tails can also influence expression, as addition of the catfish GnRHR C-tail to the rat GnRHR or addition of the Xenopus (X)GnRHR C-tail to the human or sheep (s)GnRHRs increases cell surface receptors (Lin et al. 1998, Finch et al. 2004, Caunt et al. 2006). Although the ways in which these structures influence expression are largely unknown, the importance of trafficking has been illustrated by GnRHR point mutants that cause infertility, apparently by misrouting otherwise functional receptors. Here, a key observation is that a membrane-permeant GnRHR antagonist (IN3) facilitates signaling via several of these mutant hGnRHRs (Janovick et al. 2002, 2003, 2006, Brothers et al. 2004, Ulloa-Aguirre et al. 2004, Knollman et al. 2005, Sedgley et al. 2006). This antagonist is thought to act as a pharmacological chaperone, enabling the protein to fold appropriately for ER exit, and thereby overcoming the inhibitory effect of the mutations. The IN3 also caused a modest increase in $\left[{ }^{3} \mathrm{H}\right] \mathrm{IP}$ accumulation mediated by the wild-type GnRHR, and it was suggested that as much as 50\% of the hGnRHR does not traffic to the PM in COS7 cells (Brothers et al. 2004). Indeed, the inefficient trafficking of wild-type hGnRHRs may predispose them to inhibitory effects of mutations that further impair trafficking (Janovick et al. 2002, 2003, Brothers et al. 2004, Ulloa-Aguirre et al. 2004, Knollman et al. 2005).

GnRH-stimulated gonadotropin secretion can be blocked with antagonists or mimicked by agonists, but in the latter case, sustained stimulation causes desensitization. Thus, both treatments ultimately reduce circulating levels of gonadotropins and gonadal steroids, causing the 'medical castration' that underlies the use of GnRH analogs to treat steroid hormonedependent neoplasms such as those of the prostate, ovary, endometrium, or mammary (Schally 1999). In addition to expression in the pituitary, GnRHRs are found (often along with $\mathrm{GnRH}$ ) in many cancers of reproductive tissues (Cheng \& Leung 2005). Interest in these extrapituitary GnRHRs stems primarily from the fact that $\mathrm{GnRH}$ analogs (or their cytotoxic derivatives) can inhibit proliferation of cell lines derived from such cancers, and that direct anti-proliferative effects may therefore contribute to the therapeutic effects of GnRH analogs in cancer treatment (Eidne et al. 1987, Kakar et al. 1994, Imai et al. 1997, Emons et al. 1998, Schally \& Nagy 1999, Everest et al. 2001, Limonta et al. 2003, Moretti et al. 2003, Cheng \& Leung 2005). In recent studies exploring the context dependence of GnRHR signaling, we have used recombinant adenovirus (Ad) to express GnRHRs in hormone-dependent cancer cells that lack endogenous GnRHRs (as judged by whole cell radioligand binding and $\left[{ }^{3} \mathrm{H}\right] \mathrm{IP}$ accumulation experiments). In MCF7 breast cancer cells (for example), transduction with $\mathrm{Ad}$ sGnRHR caused expression of high-affinity $G_{\alpha q}$-coupled receptors that mediated a potent antiproliferative effect of GnRH agonists (Everest et al. 2001, Finch et al. 2004). Antiproliferative effects in Ad hGnRHR-infected cells were consistently lower than those in Ad sGnRHR-infected cells, corresponding to lower cell surface expression of the hGnRHR, and we speculated that inefficient delivery to the PM might be an important determinant of hGnRHR function in hormonedependent cancer cells (18). Here, we describe a novel system for GnRHR quantification based on semi-automated acquisition and analysis of digital fluorescence images of N-terminal HA-tagged GnRHRs at the cell surface and within cells. Using this, we have determined the proportion of GnRHRs at the cell surface. We show that the proportion of HA-tagged hGnRHRs at the cell surface is remarkably low in hormonedependent cancer cell lines $(<1 \%)$ and that the proportion of GnRHRs can be increased by both peptide and non-peptide antagonists, observations that may be important for therapeutic use of such compounds.

\section{Materials and Methods}

\section{Materials}

Peptides were from Sigma except for Buserelin ([T-BuSer ${ }^{6}$, Pro $^{9}$ NH ethylamide] GnRH) which was provided by Prof. J Sandow (Aventis Pharma GmbH, Frankfurt, Germany). Myo$\left[2-{ }^{3} \mathrm{H}\right]$ inositol $(10-25 \mathrm{Ci} / \mathrm{mmol})$ was from NEN (PerkinElmer, Boston, MA, USA). The membrane-permeant GnRHR antagonist, IN3 ((2S)-2-[5-[2-(2-axabicyclo[2.2.2]oct-2-yl)-1,1-dimethy-2-oxoethyl]-2-(3,5-dimethylphenyl)1H-indol-3-yl]-N-(2-pyridin-4-ylethyl)propan-1-amine), was provided by Dr Ashton Wallace (Merck and Co. Inc). Culture media were from Gibco BRL and plasticware was from Corning (supplied by Appleton Woods, Birmingham, UK) or Nunc (supplied by Fisher, Loughborough, UK). Sera were from First Link (Brierly Hill, UK) and antibodies were from Invitrogen or Cambridge Biosciences (Cambridge, UK). cDNAs encoding wild-type GnRHRs were provided by Prof. R Millar (Medical Research Council Human Reproductive Sciences Unit, Edinburgh, UK).

\section{Engineering of receptors, cell culture, and transfection}

Recombinant, E1 deleted Ad expressing hGnRHRs, mGnRHRs, XGnRHRs, or h.XGnRHRs (chimeras consisting of the hGnRHR with an added XGnRHR C-terminal tail) 
were prepared and used as described (Everest et al. 2001, Hislop et al. 2001, 2005, Franklin et al. 2003, Caunt et al. 2004, 2006). For imaging, the Ad expressing the N-terminal HA-tagged equivalents of these receptors were prepared as described (Sedgley et al. 2006). MCF7 and DU145 cells from the European Collection of Cell Cultures (Salisbury, UK) were routinely cultured in Dulbecco's modified Eagle's medium (DMEM) with $10 \%$ fetal calf serum (FCS), $2 \mathrm{mM}$ L-glutamine, $50 \mathrm{IU} / \mathrm{ml}$ penicillin, and $50 \mathrm{~g} / \mathrm{ml}$ streptomycin. For imaging experiments, they were plated in 96-well Corning Costar plates (Appleton Woods) or Greiner Micro Clear plates (BioOne, Gloucester, UK). For some experiments, the MCF7 cells were plated in Greiner Micro Clear plates that had been pre-coated with Matrigel basement membrane (BD Biosciences, supplied by Biotrace Fred Baker Ltd, Runcorn, UK) following the manufacturer's instructions. L $\beta$ T2 cells (gonadotrope lineage cells provided by Prof. P Mellon, University of San Diego, CA, USA) were maintained in serum-supplemented DMEM (Hislop et al. 2005) in Matrigel-coated T75 flasks. For experiments, they were plated (2500 cells/well) in Matrigel-treated Greiner Micro Clear plates. GnRHRs were transiently expressed by infection with Ad (6-h incubation, the day after plating) and assays were then performed within $24 \mathrm{~h}$ of transduction. In the first experiments, (Fig. 1) Ad titers of 30-300 pfu/nl were used. Thereafter, titers giving comparable whole cell expression levels (300 pfu/nl for hGnRHRs, $100 \mathrm{pfu} / \mathrm{nl}$ for XGnRHRs and h.XGnRHRs) were used throughout.

\section{Quantification of receptor expression by cell imaging}

Cell surface and whole cell HA-GnRHR expression levels were measured by fluorescence microscopy using a semi-automated system for image acquisition (IN Cell Analyzer 1000, GE Healthcare UK Ltd, Little Chalfont, UK), and validated algorithms for image segmentation and quantification (IN Cell Analyzer version 1.0 software). Briefly, cells were cultured in 96-well plates at 2500-5000 cells/well, infected with Ad HA-GnRHRs (as above) and left for 16-24 h prior to staining. For cell surface receptor staining, they were incubated for $1 \mathrm{~h}$ at $4{ }^{\circ} \mathrm{C}$ with the primary antibody (mouse monoclonal anti-HA11 , clone $16 \mathrm{~B} 12$, stock at 5-7 $\mathrm{mg} / \mathrm{ml}$ diluted 1:200 in DMEM with $1 \%$ BSA) and then washed with ice-cold PBS, fixed (30 min in $2 \%$ paraformaldehyde/PBS) then permeabilized $(10 \mathrm{~min}$ in PBS $/ 0 \cdot 1 \%$ Triton $\mathrm{X}-100)$. The cells were then washed $(3 \times)$, blocked ( $1 \mathrm{~h}$ in PBS/0.1\% Triton X-100/1\% BSA), and incubated $1 \mathrm{~h}$ with the secondary antibody (Alexa Fluor 488 conjugated goat anti-mouse IgG at 1:500 in PBS/01\% Triton $\mathrm{X}-100 / 1 \%$ BSA). They were then washed with PBS $(2 \times)$, incubated with $2 \mu \mathrm{M} \mathrm{4}$ ',6-Diamidino-2-phenyindole (DAPI, $15 \mathrm{~min})$, and washed $(3 \times)$ before imaging. For whole cell staining, cells were washed with PBS, fixed, permeabilized, and blocked as above before being exposed to the anti-HA primary antibody. They were then washed with PBS $(3 \times 5 \mathrm{~min})$, incubated with Alexa Fluor 488 conjugated anti-mouse IgG and DAPI. Digital images were acquired, collecting one to four fields per well with a $10 \times$ objective (Plan Apochromat,
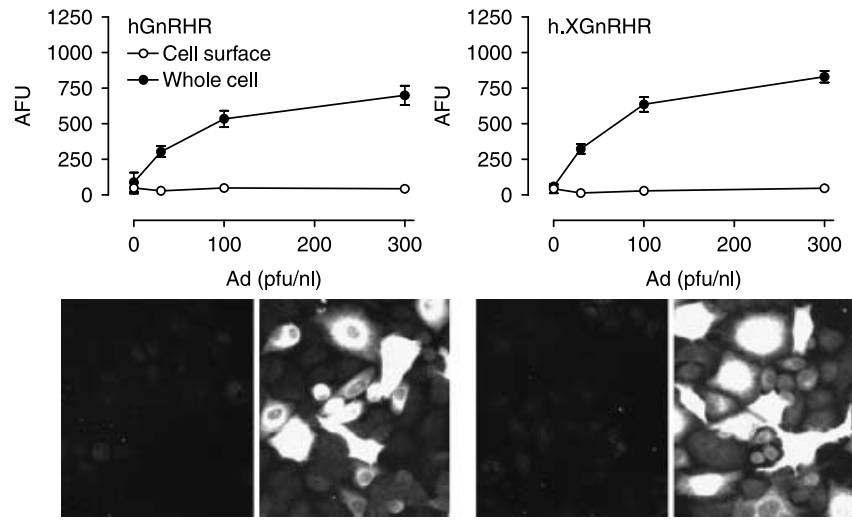
surface hGnRHR

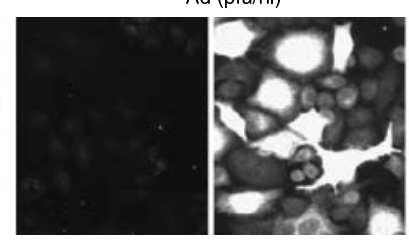

Cell

surface

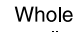

h. XGnRHR
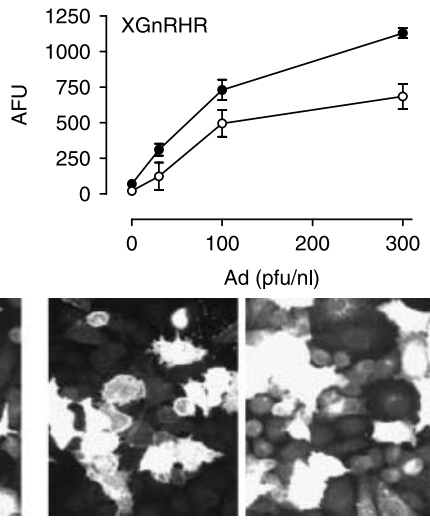

Cell surface XGnRHR

Figure 1 Relationship between Ad titer and receptor expression in Ad GnRHR-infected MCF7 cells. MCF7 cells infected with the indicated titers of Ad expressing N-terminal HA-tagged hGnRHRs, h.XGnRHRs, or XGnRHRs were stained for cell surface receptors (incubation of intact cells with primary antibody) and nuclei (DAPI) or for whole cell receptor expression (permeabilization before primary antibody addition), prior to image acquisition and analysis as described in the Materials and Methods. The upper figures show stain intensity (arbitrary fluorescence units, AFU) at the cell surface (open symbols) or throughout the cell (whole cell, filled symbols) in the positive cells in a single representative experiment (mean \pm S.E.M., $n=4)$. The lower panels show representative images of HA-GnRHR staining at the cell surface or throughout the whole cell and are from cells infected with Ad hGnRHR at $300 \mathrm{pfu} / \mathrm{nl}$, and Ad h.XGnRHR or Ad XGnRHR each at $100 \mathrm{pfu} / \mathrm{nl}$ (as indicated). These images show $<1 \%$ of the total area imaged to generate the graphs shown. Two-way ANOVA revealed that Ad titer and permeabilization were statistically significant variables $(P<0 \cdot 01)$ for each receptor type. 
numerical aperture 0.45 ) in order to obtain images of 100 1000 cells (per well) in a total imaged area of $0 \cdot 6-2 \cdot 4 \mathrm{~mm}^{2}$. These images were then segmented and quantified using the IN Cell 1000 Analyzer software (Dual Area Analysis Algorithm version 1.0 from GE Healthcare). After subtraction of background fluorescence (measured in cell-free regions), this analysis provided fluorescence intensity in arbitrary fluorescence units (AFU) per cell and per well. As an alternative measure, we also defined the proportion of imaged cells expressing measurable HA-GnRHRs (cells in which fluorescence was $>10 \%$ above background) and compounded these values $(\%+$ ve cells $\times$ AFU in + ve cells) as an expression index. In most experiments, the expression index obtained without permeabilization (cell surface expression index) was then expressed as a percentage of the expression index obtained with permeabilization (whole cell expression index) to calculate the proportional cell surface expression (PCSE). Non-specific labeling was negligible, with these protocols as revealed by the low fluorescence intensity in control cells receiving no Ad (Fig. 1) or by omission of primary or secondary antibody (not shown).

\section{$\left.P^{3} H\right]$ Inositol phosphate (IP) accumulation}

$\left[{ }^{3} \mathrm{H}\right] \mathrm{IP}$ accumulation was used as a measure of PLC activity in cells labeled with $\left[{ }^{3} \mathrm{H}\right]$ inositol and stimulated for $60 \mathrm{~min}$ with varied concentrations of Buserelin in the presence of $10 \mathrm{mM}$ $\mathrm{LiCl}$ as described (Everest et al. 2001. Hislop et al. 2001, Sedgley et al. 2006). To test for effects of IN3, this was either included during the incubation with Buserelin (co-incubation) or was added immediately after Ad transduction and during the co-incubation (e.g. present during a 16-h pre-treatment as well as the co-incubation).

\section{Quantification of nuclear stains by cell imaging}

Cell imaging was also used to assess effects of various treatments on cell number. To do so, cells were plated at low density (250500 cells/well) in 96-well plates, transduced with HA-GnRHRs (as above), and then incubated for 16-24 h in reduced serum medium (culture medium as above but with only $2 \%$ FCS). Test compounds were then added and the cells were incubated for a further $24 \mathrm{~h}$ before addition of Hoechst 33342 trihydrochloride trihydrate (Hoechst, $1.25 \mu \mathrm{g} / \mathrm{ml}$ final concentration) to stain nuclei. Digital images were then obtained (using the $10 \times$ objective) and nuclei were defined (as above). In addition to cell number, this method provides information on nuclear size, shape, and stain intensity that can be used to probe population dynamics (Mukherji et al. 2006). Frequency distribution curves of integrated nuclear Hoechst stain intensity (mean fluorescence $X$ nuclear area) showed the characteristic biphasic distribution with distinct $2 \mathrm{n}$ and $4 \mathrm{n}$ peaks (e.g. G1/G0 and G2/S cells respectively) as well as cells with less intense nuclear staining. In preliminary experiments, we found no measurable effect of our test compounds on the $2 \mathrm{n}$ or $4 \mathrm{n}$ populations but the proportion of cells with low nuclear staining was regulated. Accordingly, we defined a sub-2n (putative apoptotic) population as cells in which the integrated nuclear stain intensity was $<50 \%$ of the value for the $2 \mathrm{n}$ peak. As a measure of proliferation, we also defined the proportion of cells with small and intensely stained anaphase nuclei (that were characteristically seen in pairs) and used this as a mitotic index. These nuclei were classified with a user-defined training cell population and software-defined discrimination parameters (nuclear area, integrated nuclear stain intensity, and the coefficient of variance of stain intensity within the nucleus) using the Supervised Classifier option of the IN Cell 1000 Analyzer software. In this way, we used the nuclear stain to generate indices of apoptosis and mitosis in parallel with cell numbers.

\section{Statistical analysis and data presentation}

The figures show the data (mean \pm s.E.M.) of three or four wells in single experiments that are representative of at least two similar experiments, or show data pooled from at least three independent experiments. For pooling $\left[{ }^{3} \mathrm{H}\right] \mathrm{IP}$ accumulation, data were normalized to the maximal response to Buserelin in control cells. Statistical analysis was by two-way ANOVA and Student's $t$-test, accepting $P<0 \cdot 05$ as statistically significant.

\section{Results}

Imaging of epitope-tagged GnRHRs in MCF7 cells

The initial aim of these experiments was to develop an efficient means of defining the proportion of GnRHRs at the cell surface. To do so, we expressed N-terminal HA-tagged human (h) and Xenopus laevis (X) GnRHRs and a chimeric receptor consisting of the hGnRHR sequence in tandem with the C-terminal tail of the XGnRHR (h.XGnRH) in MCF7 cells by infection with recombinant Adenovirus (Ad). Cell surface and whole cell receptor expression was then determined by fluorescence microscopy followed by semi-automated imaging. The HA-GnRHR staining was used to determine the proportion of cells that were positively stained (fluorescence $>10 \%$ above background) and the stain intensity in the positive cells (arbitrary fluorescence units, AFU). As expected, increasing Ad titer caused an increase in whole cell receptor expression as judged by increased AFU in the positively stained cells for all three receptors (Fig. 1), and stain specificity is evident from the lack of staining in cells without HA-GnRHRs. The titer-dependent increase in staining was paralleled by an increase in the proportion of cells that were positively stained (below). Increasing Ad XGnRHR titer also caused a clear increase in cell surface receptor expression as judged by both AFU in positive cells (Fig. 1) and the proportion of cells that were positively stained (not shown) but cell surface expression was much lower (by either measure) in cells infected with Ad hGnRHR or Ad h.XGnRHR (Fig. 1).

These data suggest that the proportion of XGnRHRs at the cell surface is much greater than that for the hGnRHR or 
h.XGnRHR but an obvious concern is that overexpression might influence this distribution. To address this, we infected cells with Ad titers selected for comparable whole cell expression (Ad hGnRHR at $300 \mathrm{pfu} / \mathrm{nl}$, Ad h.XGnRHR and XGnRHR at $100 \mathrm{pfu} / \mathrm{nl}$ ) and, in order to determine the influence of the molecular chaperone, cells were cultured for $16 \mathrm{~h}$ in the presence or the absence of IN3 $\left(1 \cdot 8 \times 10^{-8} \mathrm{M}\right)$ before staining. In these experiments, we defined the proportion of cells that are positively stained as well as the stain intensity in these cells, and then calculated an 'expression index' by compounding these values. Here, our intention was to mirror the situation in conventional cellular binding assays (where receptor binding reflects both the proportion of cells expressing the receptor and the expression level within those cells) and representative images are shown (Fig. 2 lower panel) to illustrate the image segmentation and identification of positively stained cells. Cell surface and whole cell expression indices were then used to determine the proportion of receptors at the cells surface (PCSE). As shown in Fig. 2, cell surface expression of h.XGnRHRs was slightly greater than that of hGnRHRs (as judged by $\%+$ ve, AFU or by the expression index) and whole cell values were comparable (by all three parameters). The PCSE for hGnRHRs was very low $(0 \cdot 34 \%)$ and was increased $7 \cdot 0 \pm$ 1.8-fold by IN3 (Fig. 2F). The PCSE for h.XGnRHRs was a little higher $(0 \cdot 64 \%)$ and was increased $15 \cdot 1 \pm 1 \cdot 2$-fold by IN3. The PCSE for XGnRHRs was much greater than that of the other two receptors and was unaltered by IN3 (below). IN3 also tended to increase whole cell expression levels of both receptors
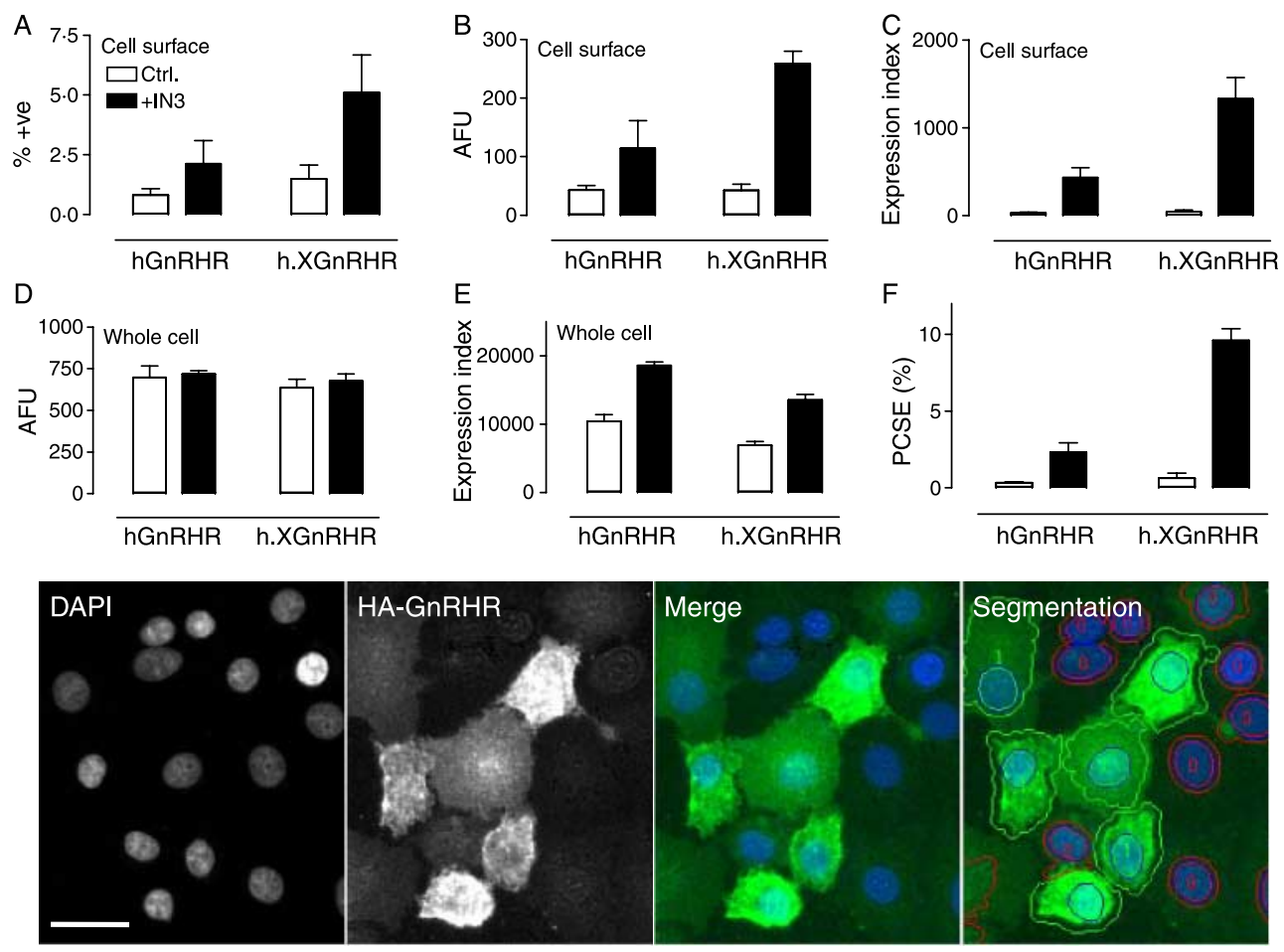

Figure 2 GnRHR localization at matched whole cell expression levels. MCF7 cells were treated as described for Fig. 1 except that they were incubated for $16 \mathrm{~h}$ with 0 (open bars) or $1 \cdot 8 \times 10^{-7} \mathrm{M} \mathrm{IN} 3$ (filled bars) before staining for $\mathrm{HA}$-tagged receptors in intact (cell surface) and permeabilized (whole cell) cells as indicated. The figure shows the proportion of cells with cell surface staining $(\%+v e$, panel $A)$, the cell surface staining in those cells (AFU, panel B), and the expression index calculated by compounding these values (panel C). Fluorescence intensity and expression index were also determined for whole cell staining (panels D and E respectively) and used for calculation of the proportion of receptors at the cell surface (proportional cell surface expression, PCSE, panel F). These data are from the experiment shown in Fig. 1 (mean \pm s.E.M., $n=4$ ) with Ad titers selected for comparable whole cell expression levels (300 pfu/nl for Ad hGnRHR and $100 \mathrm{pfu} / \mathrm{nl}$ for Ad h.XGnRHR). Parallel experiments with the XGnRHR (100 pfu/nl) yielded PCSE values of $39 \cdot 1 \pm 5 \cdot 9$ and $59 \cdot 1 \pm 25 \cdot 6$ in control and IN3-treated cells respectively. Two-way ANOVAs of the graphed data revealed IN3 as a significant variable for each measure except for AFU in whole cells (e.g., $P<0.05$ for panels $A-C$, and $F$, but not for panel $D$ ). The lower panel images show representative views of DAPI-stained nuclei and HA-GnRHR expressing cells as well as merged images. Segmentation is also shown (lower right) to illustrate how the individual cells were filtered to identify HA-GnRH positive cells (green outlines, AFU $>10 \%$ above background) and negative cells (red outlines, AFU $<10 \%$ above background). Full colour version of this figure available via http://dx.doi.org/10.1677/JOE-07-0471. The horizontal scale bar (DAPI image) is $\sim 20 \mu \mathrm{m}$. 
(Fig. 2E) but this effect was not significant with data pooled from the whole series of experiments (not shown). Its major effect was to increase the proportion of hGnRHRs and h.XGnRHRs at the cell surface and thereby increase cell surface expression. Pooling data from the entire data series revealed control PCSE values of $0 \cdot 6 \pm 0 \cdot 1,1 \cdot 4 \pm 0 \cdot 5$, and $39 \cdot 1 \pm 5 \cdot 6 \%$ (for the hGnRHR, h.XGnRHR, and XGnRHR respectively) and IN3-treated PCSE values of $6 \cdot 1 \pm 0 \cdot 6,12 \cdot 8 \pm 1 \cdot 7$, and $45 \cdot 9 \pm 9 \cdot 8$ (again, for the hGnRHR, h.XGnRHR, and XGnRHR respectively).

We next explored the concentration and time dependence of the IN3 effects on cell surface expression of the hGnRHR and h.XGnRHR. As shown in Fig. 3, the IN3 effects were time dependent, reaching maxima between 8 and $24 \mathrm{~h}$, and changes in the cell surface expression index were paralleled by changes in the proportion of receptors at the cell surface. The IN 3 effects on cell surface expression of these receptors were also concentration dependent (Fig. 4) with 50\% effective concentration $\left(\mathrm{EC}_{50}\right)$ values of $3-5 \times 10^{-8} \mathrm{M}$ for both receptors. Although kinetics and concentration dependencies were indistinguishable, maximal cell surface receptor expression levels were consistently greater with the h.XGnRHR than with the hGnRHR (Figs 3 and 4).

\section{Context-dependence of GnRHR expression}

We have suggested that the proportion of hGnRHRs expressed at the cell surface may be dependent upon the cell type (Sedgley et al. 2006), and have explored this using our imaging assay in MCF7 breast cancer cells and DU145 prostate cancer cells. As shown in Fig. 5, expression data were comparable in these cell lines. In both lines, the PCSE was low $(<1 \%)$ for the hGnRHR and a little higher (1-2\%) for the h.XGnRHR. The IN3 significantly increased PCSE values without measurably influencing whole cell expression (not shown) so that qualitatively similar data were obtained for the cell surface expression index and the PCSE values (Fig. 5). We next compared expression in MCF7 and L $\beta$ T2 (gonadotrope lineage) cells. In preliminary experiments, we found it necessary to use Matrigel-coated plates for the L $\beta$ T2 cells (because they washed off uncoated plates) and therefore included MCF7 cells on uncoated and Matrigel-coated plates for comparison. As expected, the PCSE values were relatively low for the hGnRHR and h.XGnRHR in MCF7 cells and were significantly increased by pre-incubation with IN3, irrespective of the Matrigel treatment of the plates. Expression levels were considerably higher for both receptors in the gonadotrope lineage cells $(5 \cdot 1 \pm 1 \cdot 8$ and $11 \cdot 5 \pm 2 \cdot 6 \%$ for the
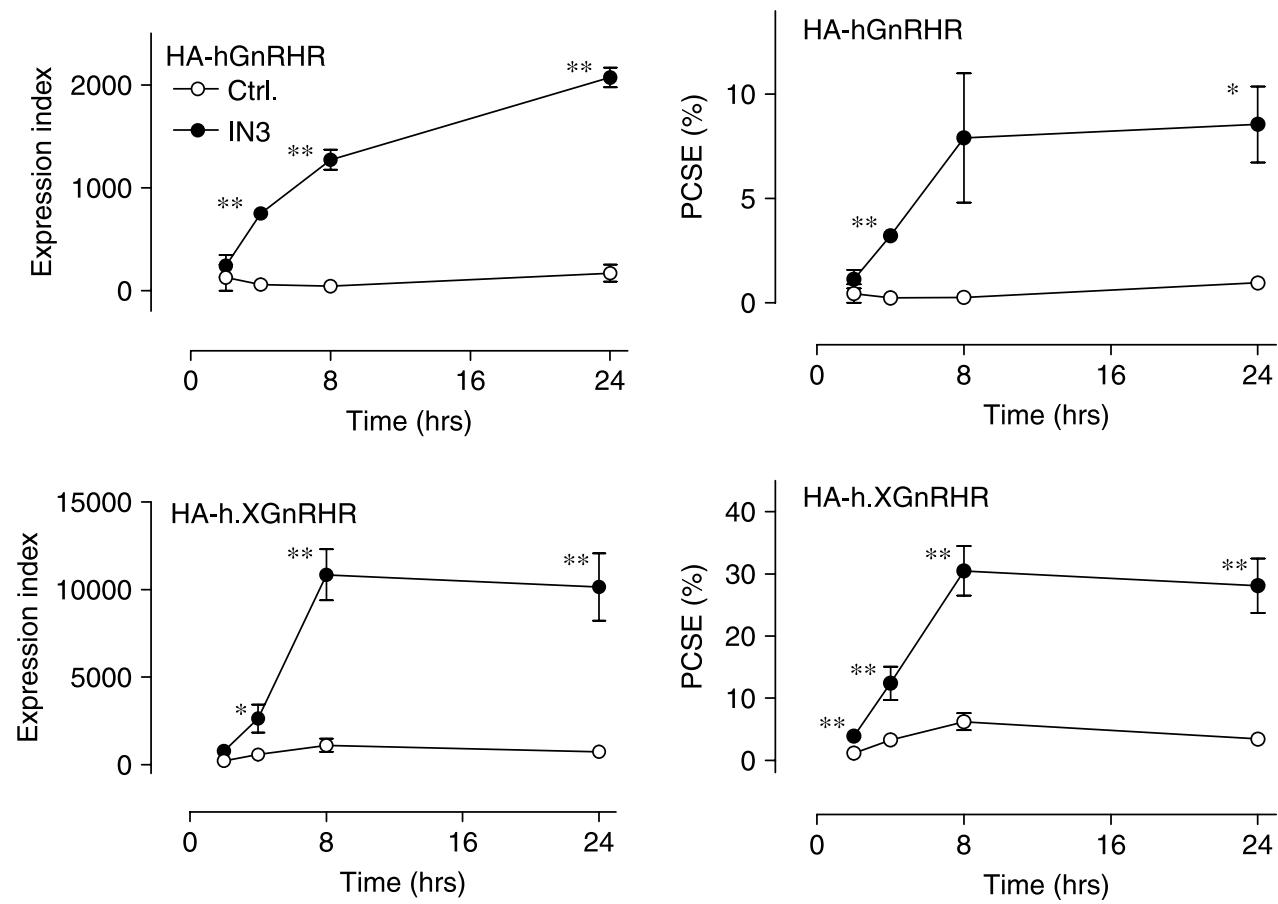

Figure 3 Time dependence of the IN3 effect on plasma membrane expression of HA-GnRHRs. MCF7 cells infected with Ad HA-hGnRHRs (upper panels) or Ad HA-h.XGnRHRs (lower panels), incubated for the indicated time with 0 (open circles) or $1 \cdot 8 \times 10^{-7} \mathrm{M}$ (filled circles) IN3 prior to staining and imaging as described under Fig. 2. The figure shows expression indices (left panels) and the PCSE values (right panels) pooled from four separate experiments (mean \pm S.E.M., $n=4$ ) each with quadruplicate observations. Two-way ANOVA revealed time and IN3 as significant variables for each panel $(P<0 \cdot 01)$. IN3 effects were statistically significant $\left({ }^{*} P<0 \cdot 05,{ }^{* *} P<0 \cdot 01\right.$ using Student's $t$-test) compared with time-matched controls, as indicated. 


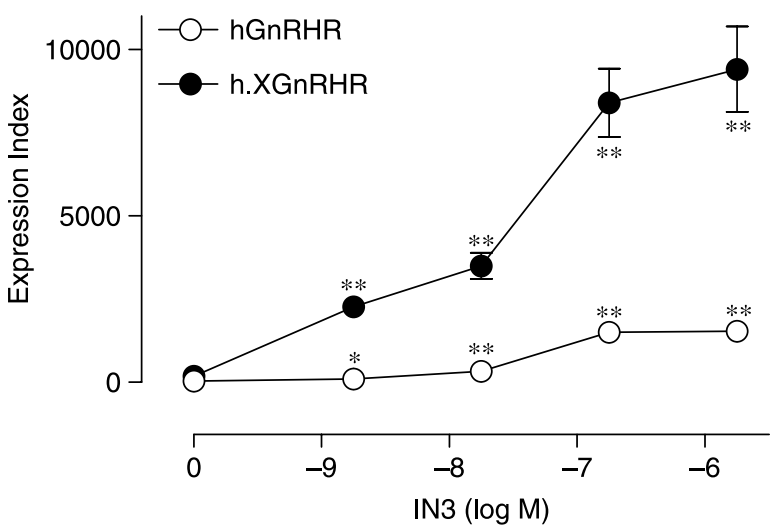

Figure 4 Concentration dependence of the IN3 effect on plasma membrane expression of HA-GnRHRs. MCF7 cells were transduced with Ad HA-GnRHRs and incubated for $16 \mathrm{~h}$ with the indicated concentration of IN3 prior to staining and imaging. Data shown are cell surface expression indices from a representative experiment. Two-way ANOVA revealed receptor type and concentration as significant variables $(P<0 \cdot 01)$ and IN3 significantly increased cell surface GnRHR expression as indicated $\left({ }^{*} P<0 \cdot 05, * * P<0 \cdot 01\right.$ by Student's $t$-test).
hGnRHR and h.XGnRHR respectively) and the effects of IN3 were much less pronounced. Thus, IN3 increased the PCSE for hGnRHRs and h.XGnRHRs by $18 \cdot 4 \pm 4 \cdot 1-$ and $7 \cdot 0 \pm 1 \cdot 1$-fold respectively in MCF7 cells but caused only $2 \cdot 7 \pm 0 \cdot 4-$ and $1 \cdot 7 \pm 0 \cdot 1$-fold increases (respectively) in expression of the same receptors in L $\beta$ T2 cells (Fig. 6).

\section{Effects of IN3 on GnRHR function}

We next explored possible functional correlates of the MCF7 cell imaging data, using non-tagged GnRHRs. To do so, we determined the effect of IN 3 on $\left[{ }^{3} \mathrm{H}\right] \mathrm{IP}$ accumulation mediated by the hGnRHR, h.XGnRHR, or mouse (m) GnRHR. As shown in Fig. 7, Buserelin caused a robust increase of $\left[{ }^{3} \mathrm{H}\right] \mathrm{IP}$ by activation of all three receptors and when co-incubated with Buserelin, IN3 $\left(1.8 \times 10^{-7} \mathrm{M}\right)$ behaved as a competitive antagonist, shifting the Buserelin concentration-response curve rightward (e.g., increasing the $\mathrm{EC}_{50}$ from $<1 \mathrm{pM}$ to $>10 \mathrm{nM}$ at the hGnRHR). When cells were pre-incubated for $16 \mathrm{~h}$ with $1.8 \times 10^{-7} \mathrm{M}$ IN3 (and the same concentration of IN3 was maintained throughout the stimulation with Buserelin), this inhibited the response to lower concentrations of Buserelin but actually increased the response to the higher
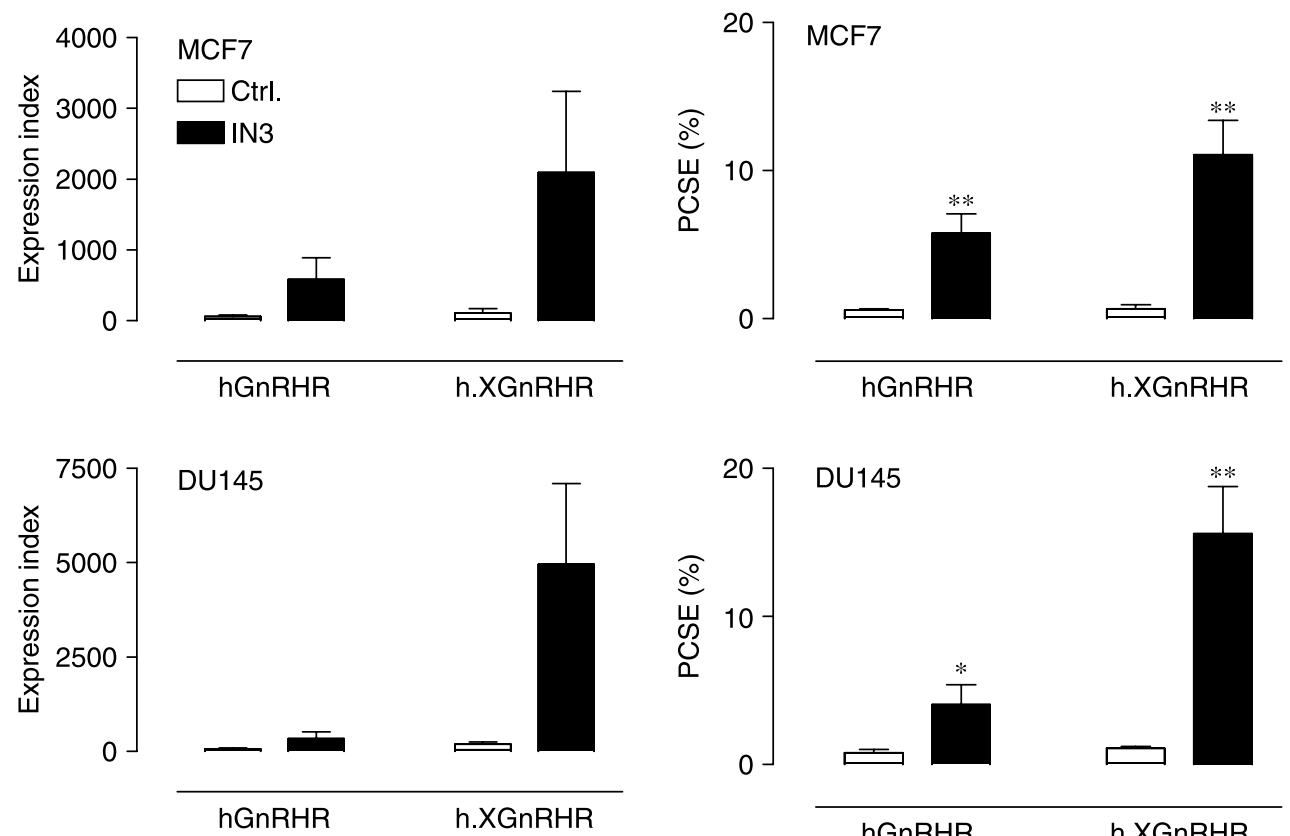

Figure 5 Effects of IN3 on plasma membrane expression of HA-GnRHRs in MCF7 and DU145 cells. MCF7 (upper panels) and DU145 (lower panels) cells infected with Ad expressing the indicated GnRHRs and incubated for $16 \mathrm{~h}$ in medium with 0 (ctrl., open bars) or $1 \cdot 8 \times 10^{-7} \mathrm{M} \mathrm{IN} 3$ (filled bars) before imaging of cell surface and whole cell receptors. The left panels show expression indices and the right panels show PCSE values, pooled from four separate experiments each with three or four replicates (mean \pm s.E.M., $n=4$ ). Twoway ANOVAs revealed IN3 as a significant variable $(P<0 \cdot 05)$ for each receptor and each endpoint, and the effects of IN3 on PCSE were statistically significant $\left({ }^{*} P<0 \cdot 05,{ }^{* *} P<0 \cdot 01\right.$ when compared with control values matched for cell and receptor type) for both receptors and both cell types. 

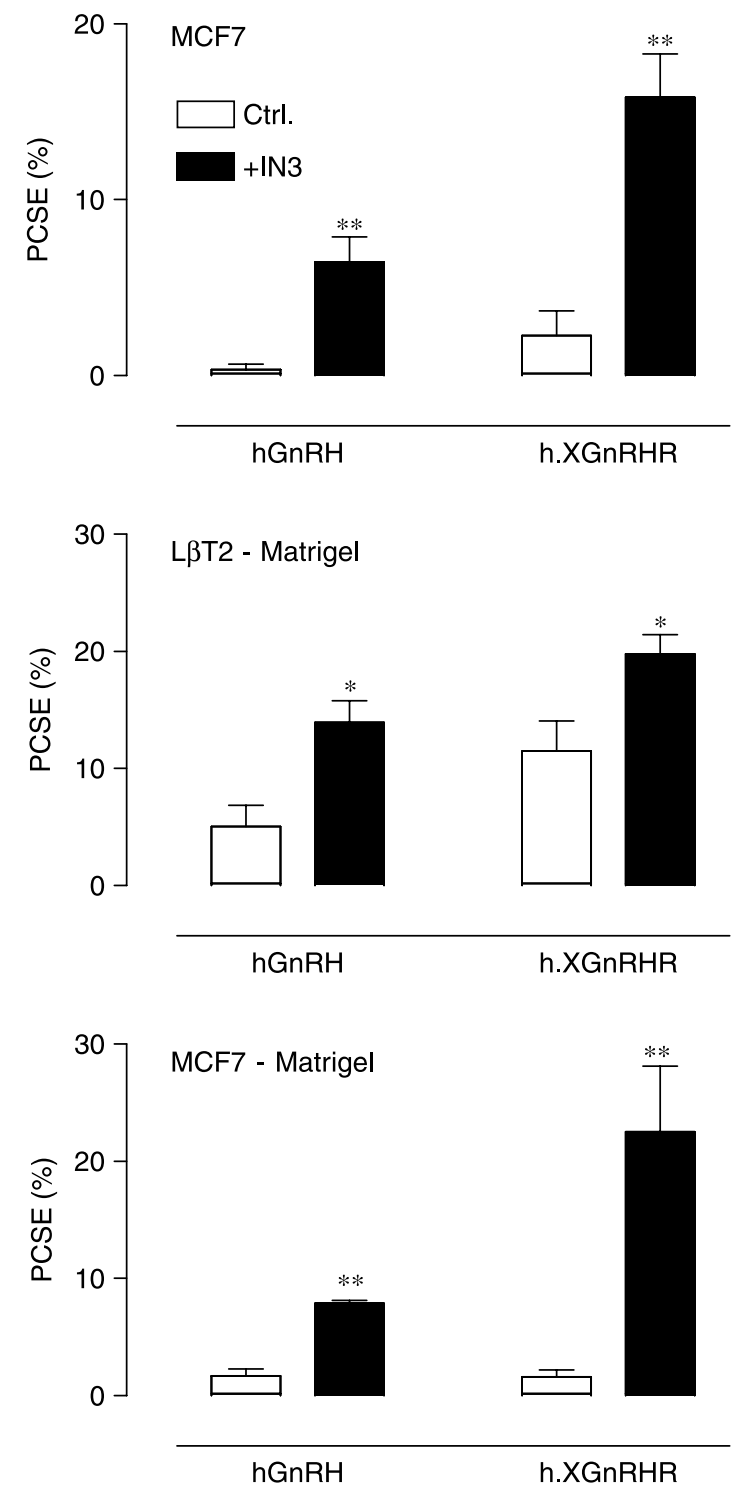

Figure 6 Effects of IN3 on plasma membrane expression of $\mathrm{HA}-\mathrm{GnRHRs}$ in MCF7 and L $\beta$ T2 cells. L $\beta T 2$ cells were cultured in plates that had been pretreated with Matrigel and MCF7 cells were either on Matrigel-treated plates (lower panel) or untreated plates (middle panel). The cells were infected with Ad expressing HA-tagged GnRHRs and then incubated for $16 \mathrm{~h}$ in medium with 0 (control) or $1.8 \times 10^{-7} \mathrm{M} \mathrm{IN} 3$, as indicated, before imaging. The figure shows PCSE values pooled from seven separate experiments each with four replicates (mean \pm S.E.M., $n=4-7$ ). ANOVAs revealed IN3 as a significant variable $(P<0 \cdot 01)$ and the effects of IN3 were statistically significant $\left({ }^{*} P<0 \cdot 05,{ }^{*} P<0 \cdot 01\right.$ when compared with control values for matched cell and receptor type) for both receptors and both cell types.

Buserelin concentrations (Fig. 7A). We have found it difficult to completely wash IN3 pre-treatments from cells, so the effect of the pre-treatment was calculated by subtraction of the responses obtained in cells co-incubated with IN3 and Buserelin, from responses obtained in cells pre- and co-incubated with IN3. Since these responses are measured under conditions of identical proportional receptor occupancy, this difference represents the increased response due to the pre-treatment with IN3 and as expected the IN3 pre-treatment caused a pronounced increase in the hGnRHR-mediated response (Fig. 7D, see also Sedgley et al. 2006). Interestingly, the IN3 pre-treatment did not measurably increase the responses mediated by the h.XGnRHR or mGnRHR (Fig. 7B-D), implying that sufficient number of these receptors are present at the cell surface for maximal activation even without IN3.

Since GnRH agonists can inhibit proliferation and/or stimulate apoptosis in hormone-dependent cancer cell lines, we also used automated imaging and analysis of Hoechst33342 stained nuclei to explore possible effects of Buserelin and IN3 on cell number. As shown in Fig. 8A, IN3 and Buserelin had no effect on cell number in control cells, but after infection with Ad hGnRHR, Buserelin caused a pronounced reduction in cell number and an even greater reduction was seen with Buserelin in the presence of IN3. Pooling data from three separate experiments revealed that IN3 had no measurable effect in Ad hGnRHR-infected cells, but the reduction in cell number caused by Buserelin was significantly greater in the presence of IN3 $(P<0 \cdot 05$, data not shown). Similar experiments were performed with cells infected with Ad h.XGnRHRs and Ad mGnRHRs (not shown) and ANOVAs with data pooled from three separate experiments revealed Buserelin as a significant variable for all three receptors, whereas IN3 was only significant for the hGnRHRs (not shown). Frequency distribution curves of Hoechst stain intensity revealed a characteristic biphasic distribution with $2 \mathrm{n}$ and $4 \mathrm{n}$ peaks, enabling us to define the proportion of cells with very low nuclear staining (integrated nuclear stain $<50 \%$ of the $2 \mathrm{n}$ peak value, Fig. $8 \mathrm{~B}$, inset). This apoptotic index was unaltered by IN3 or Buserelin in control cells but after infection with Ad hGnRHR, Buserelin caused a pronounced increase in the sub- $2 \mathrm{n}$ cells and an even greater increase was seen with Buserelin in the presence of IN3 (Fig. 8B). We also calculated a mitotic index, as the proportion of cells with small and densely stained nuclei (post-mitotic cells). This was unaltered by IN3 or Buserelin in control cells but after infection with Ad hGnRHR, Buserelin caused a pronounced reduction in the proportion of these post mitotic cells and an even greater reduction was seen with Buserelin in the presence of IN3 (Fig. 8C and D). Thus, IN3 amplifies the hGnRHR-mediated reduction in cell number, and this effect is paralleled by a reduction in the proportion of post-mitotic cells and an increase in the proportion of apoptotic cells.

\section{Comparison of peptide and non-peptide antagonists}

In the final series of experiments, we assessed whether peptide ligands could influence cell surface GnRHR expression in MCF7 cells. As expected, the membrane-permeant 
A

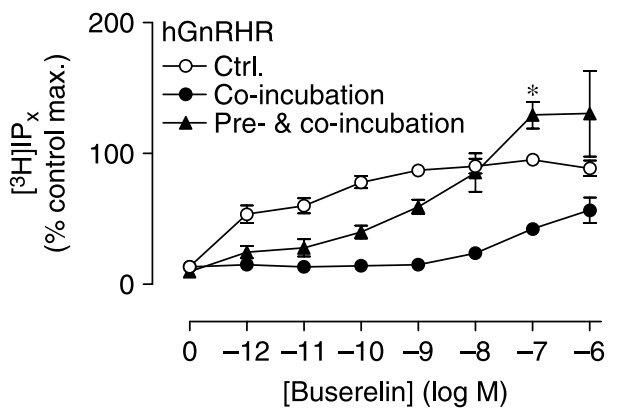

C

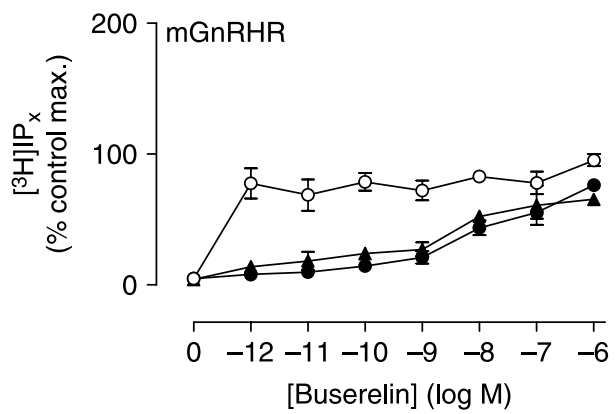

B

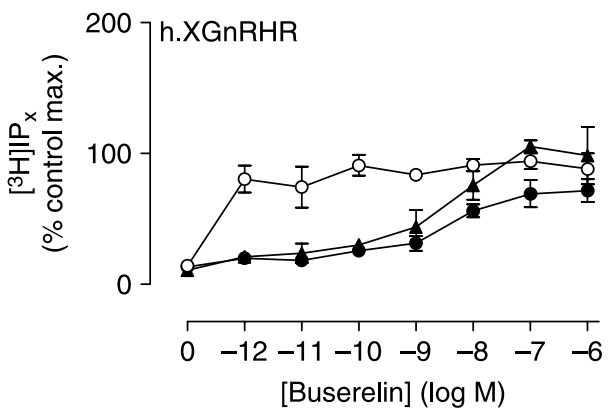

D

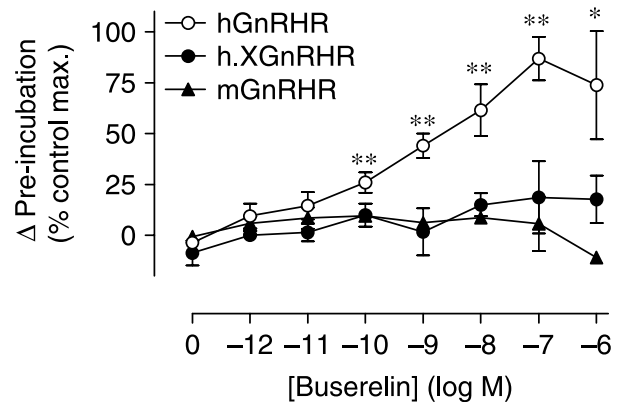

Figure 7 Effect of IN3 on GnRHR-mediated [ $\left.{ }^{3} \mathrm{H}\right]$ IP responses. MCF7 cells were infected with Ad expressing hGnRHR, h.XGnRHR, or mGnRHR and then transferred to media with 0 or $1.8 \times 10^{-7} \mathrm{MIN} 3$ and $\left[{ }^{3} \mathrm{H}\right]$ inositol (for $16 \mathrm{~h}$ ), then washed and stimulated for $1 \mathrm{~h}$ with the indicated concentration of Buserelin with $10 \mathrm{mM} \mathrm{LiCl}$ and either 0 (control) or $1.8 \times 10^{-7} \mathrm{M}$ IN3. Panels A-C show data for cells receiving no IN3 (control), as well as for cells receiving IN3 during the stimulation with Buserelin (co-incubation) or during both the 16-h pretreatment and the Buserelin stimulation (pre- and co-incubation) and these data are normalized as a percentage of the maximal response to Buserelin in control cells (those receiving no IN3). These data are pooled from three separate experiments each with triplicate observations (mean \pm s.E.M., $n=2-3$ ) and the control values were $592 \pm 52,520 \pm$ 101 , and $1337 \pm 91$ c.p.m./well $(n=3)$ for the hGnRHR, h.XGnRHR, and mGnRHR respectively. Panel D shows the increment in the response due to the IN 3 pre-incubation (e.g., the response in cells pre-treated and co-incubated with IN3 minus the response in cell receiving IN3 co-incubation alone) for all three receptors, and the data in panel $\mathrm{D}$ are calculated from those in panels A-C. Maximal hGnRHR-mediated [ $\left.{ }^{3} \mathrm{H}\right] \mathrm{IP}$ accumulation was significantly increased by pre- and co-incubation with IN3 $\left({ }^{*} P<0 \cdot 05\right.$, panel $\left.\mathrm{A}\right)$, whereas it caused no such increase in the maximal h.XGnRHR-mediated or $\mathrm{mGnRHR}$-mediated responses (panels $B$ and $C$ ). The effect of pre-incubation was statistically significant for $10^{-10}-10^{-6} \mathrm{M}$ Buserelin acting via the $\mathrm{hGnRHR}\left({ }^{* *} P<0 \cdot 01, * P<0 \cdot 05\right.$; panel $\left.\mathrm{D}\right)$ but not for any concentration of Buserelin acting via the h.XGnRHR or mGnRHR $(P>0 \cdot 1$, panel D).

non-peptide antagonist IN3 caused a pronounced increase in PCSE for the hGnRHR, and no such effect was seen with two peptide antagonists (antide and cetrorelix). The IN3 also caused the expected increase in PCSE for the h.XGnRHR and the GnRH had no measurable effect on either receptor. Surprisingly, however, both antide and cetrorelix increased the proportion of h.XGnRHRs at the cell surface (Fig. 9). These effects were relatively modest (compared with IN3 effects) and occurred without any measurable change in whole cell expression level, so that the effects on PCSE were mirrored by increases in the cell surface expression index (Fig. 9, and data not shown). The effects of these peptides on cell surface expression of h.XGnRHRs were time dependent (maximal at 24-48 h) and concentration dependent $\left(\mathrm{EC}_{50} \sim 10^{-8} \mathrm{M}\right)$ and when IN3 and the peptides were co-incubated, no functional interaction occurred (Fig. 10 and data not shown).

\section{Discussion}

When hGnRHRs are heterologously expressed, cell surface receptor numbers are low compared with other GnRHRs (e.g., type I rodent or ovine GnRHRs and type II Xenopus (X) or catfish GnRHRs; Davidson et al. 1995, Janovick et al. 2003, Ulloa-Aguirre et al. 2004, Sedgley et al. 2006). This could reflect differences in receptor synthesis and degradation influencing whole cell expression, or differences in trafficking affecting the proportion at the PM. Without reliable antibodies or PM-permeant radioligands, it has not been possible to define the proportion of endogenous GnRHRs at the cell surface but this can be explored with tagged GnRHRs. To our knowledge, the proportion of human or non-mammalian GnRHRs at the cell surface has not previously been determined; therefore, our initial aim was to develop an efficient means of doing so. Here, 
we have used Ad to express N-terminal HA-tagged GnRHRs and a semi-automatic fluorescence microscopy system to quantify GnRHR expression in whole cells (permeabilized before primary antibody addition) and at the cell surface (cells permeabilized after primary antibody addition). We have found that the proportion of HA-GnRHRs at the cell surface is dependent upon receptor structure (it is much lower for the HA-hGnRHR than the HA-XGnRHR and is increased by
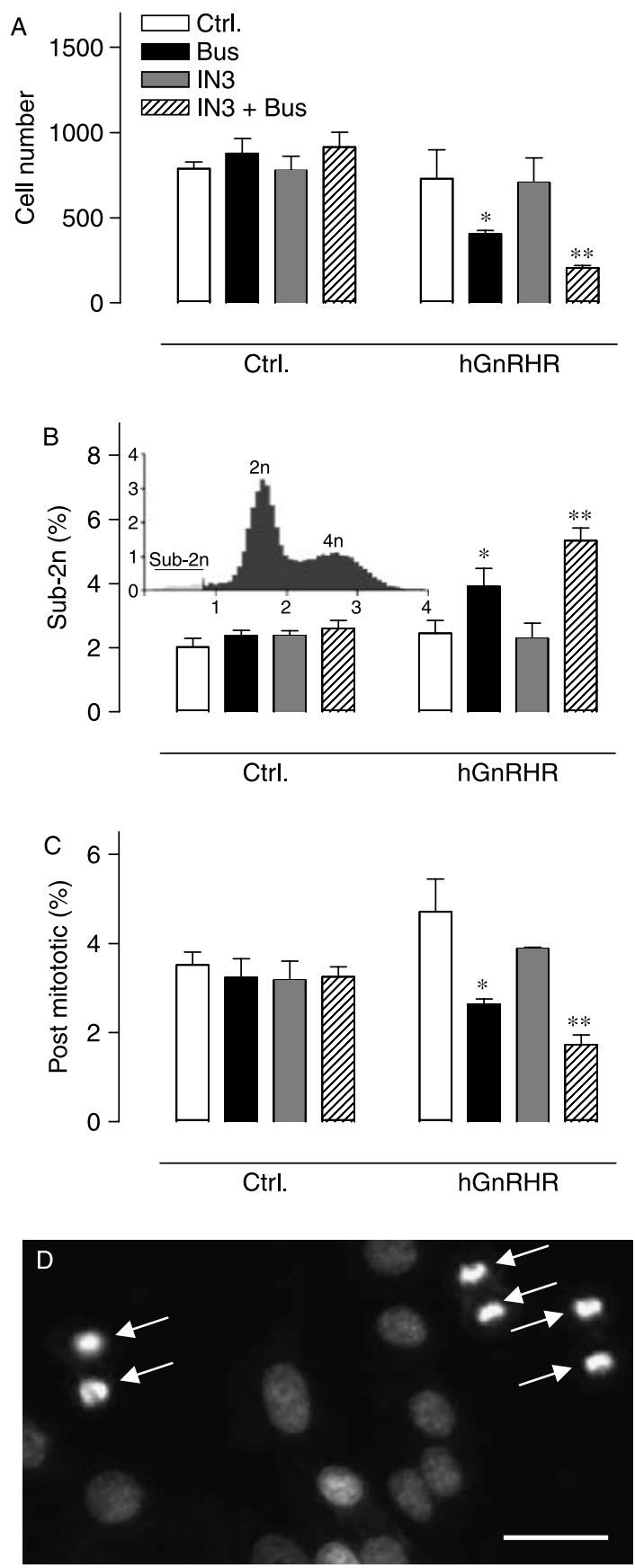

Journal of Endocrinology (2008) 196, 353-367 addition of the XGnRHR C-tail to the HA-hGnRHR), can be manipulated pharmacologically (by addition of the membranepermeant antagonist IN3), and is dependent upon cellular context (the proportion of HA-hGnRHRs at the cell surface is approximately five times greater in gonadotrope-linage L $\beta$ T2 cells than in two hormone-dependent cancer cell lines). When cell surface expression and the proportion of receptors at the cell surface were both measured, these parameters invariably changed in parallel. Thus, each of the experimental variables influenced cell surface expression by affecting the proportion of receptors at the cell surface (without any change in whole cell receptor expression levels), revealing the importance of compartmentalization as a determinant of cell surface GnRHR number.

\section{Cellular compartmentalization of GnRHRs}

The finding that $<1 \%$ of the HA-hGnRHR is resident at the cell surface is consistent with earlier work where we imaged HA-GnRHRs by confocal microscopy and found very low cell surface expression (Sedgley et al. 2006). However, it is not possible to relate quantification within a thin optical plane to distribution throughout the cell and a key difference between these approaches is that the wide-field system used here has a depth of field of $\sim 6 \mu \mathrm{m}$, which is comparable with the cell height $(\sim 5 \mu \mathrm{m}$, not shown). This quantification therefore approximates staining throughout the cell and the data herein are equivalent to that obtained with confocal $z$-stack compression but the semi-automated wide-field system is much more rapid and does not involve the potential bias of user-defined regions of interest. Our data are also consistent with the work of Conn's group, who have shown that the pharmacological chaperone IN3 increases hGnRHR-mediated $\left[{ }^{3} \mathrm{H}\right] \mathrm{IP}$ responses by $1 \cdot 5-$ to 2 -fold (using protocols with which the IN3 pre-treatment is washed from the cell prior to agonist stimulation) and have

Figure 8 Effects of Buserelin and IN3 on cell number and nuclear stains. Control and Ad hGnRHR infected cells were cultured in medium with $2 \%$ FCS with or without Buserelin $\left(10^{-7} \mathrm{M}\right)$ and IN3 $\left(1 \cdot 8 \times 10^{-7} \mathrm{M}\right)$ as indicated, prior to staining and imaging to determine cell number (in the imaged area of $2.4 \mathrm{~mm}^{2}$ ) as well as the proportion of sub- $2 \mathrm{n}$ and post-mitotic cells. The bar charts are from a single representative experiment (mean \pm s.E.M., $n=4$, ${ }^{*} P<0 \cdot 05,{ }^{* *} P<0 \cdot 01$ by Student's $t$-test). Analysis of data pooled from three similar experiments by two-way ANOVAs revealed that Buserelin was not a significant variable in control cells but was in Ad hGnRHR-infected cells $(P<0 \cdot 01)$, and in Ad hGnRHR-infected cells the reduction of cell number was greater in cells treated with IN3 and Buserelin than in cells receiving Buserelin alone $(P<0 \cdot 05$ by Student's $t$-test). The inset in panel B shows a distribution profile with integrated nuclear stain intensity on the horizontal axis (arbitrary fluorescence units) and cell number (in thousands) on the vertical axis, demonstrating the $2 \mathrm{n}$ and $4 \mathrm{n}$ cell populations and the arbitrary cut-off ( $<50 \%$ of the $2 n$ peak) used to define sub- $2 n$ cells. Panel D shows a small proportion of the image captured from a single well, illustrating the small and highly stained nuclei that were characteristically seen in pairs and identified by the analysis algorithm as post-mitotic (anaphase) cells (arrows). Horizontal scale bar $=\sim 20 \mu \mathrm{m}$. 

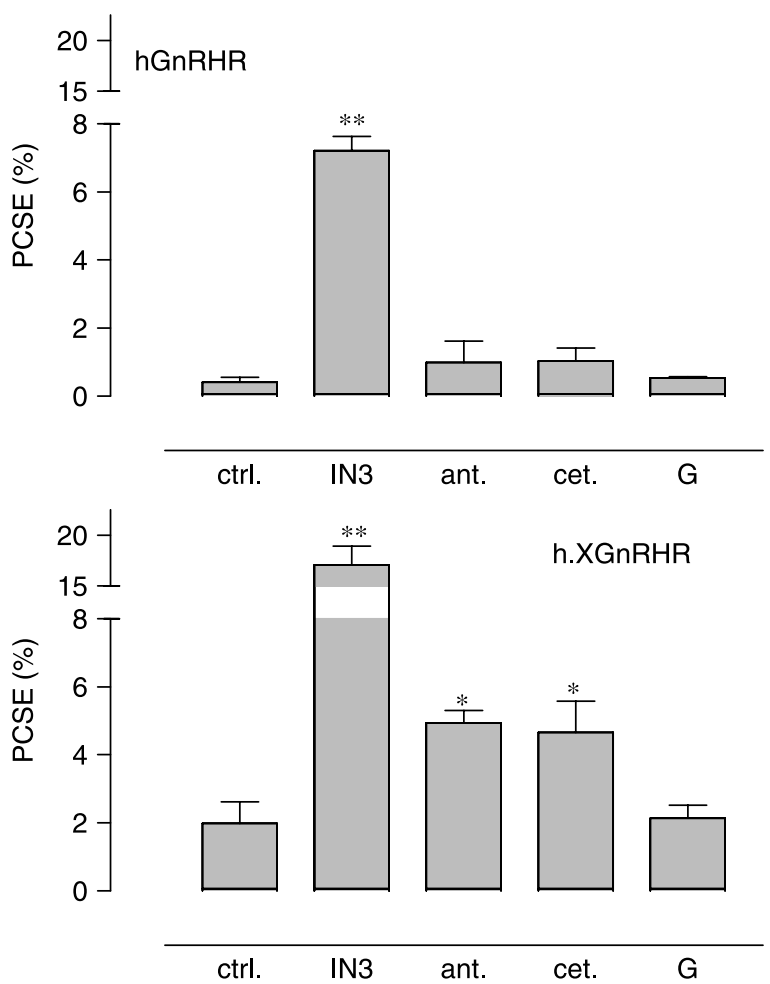

Figure 9 Effects of membrane-permeant and membrane-impermeant ligands on plasma membrane expression of HA-GnRHRs. MCF7 cells were infected with Ad expressing HA-hGnRHRs (upper panel) or h.XGnRHRs (lower panel) and then incubated for $16 \mathrm{~h}$ with control medium (ctrl.) or medium supplemented with IN3 $(1 \cdot 8 \times$ $10^{-6} \mathrm{M}$ ), antide (ant.; $\left.10^{-8} \mathrm{M}\right)$, cetrorelix (cet.; $10^{-8} \mathrm{M}$ ), or $\mathrm{GnRH}$ $\left(\mathrm{G}, 10^{-8} \mathrm{M}\right)$ before imaging. The data shown are PCSE values pooled from seven separate experiments each with three or four replicates (mean \pm s.E.M., $n=4-7$ ) and the effects of IN3 were statistically significant at both receptors, whereas the effects of antide and cetrorelix were significant only at the HA-h.XGnRHRs $\left({ }^{*} P<0 \cdot 05\right.$, $* * P<0 \cdot 01$ compared with control values for receptor type).

argued that the relatively inefficient trafficking of hGnRHRs to the PM predisposes them to effects of point mutations that further impair trafficking (Janovick et al. 2003, 2006, Ulloa-Aguirre et al. 2004, Brothers et al. 2004, Knollman et al. 2005). They have suggested (Brothers et al. 2004) that only 50\% of the hGnRH is trafficked to the PM, whereas our data reveal $<1 \%$ at the surface in MCF7 cells. We suspected that this remarkably low PCSE was due to overexpression but this is clearly not the case as we found a PCSE of $<1 \%$ for the HA-hGnRHR as compared with $\sim 40 \%$ for the XGnRHR under conditions where whole cell expression levels are indistinguishable (Fig. 2). Moreover, maximal cell surface expression of hGnRHRs in this model is only 1-2000 sites per cell (Finch et al. 2004), as compared with $\sim 80000$ sites per cell for the endogenous mouse GnRHRs of $\alpha \mathrm{T} 3-1$ cells (McArdle et al. 1992). An alternative possibility is that the $\mathrm{N}$-terminal HA-tag may have influenced receptor function but we have found that these tags do not influence affinity, specificity, cell surface expression levels, or potency in radioligand binding
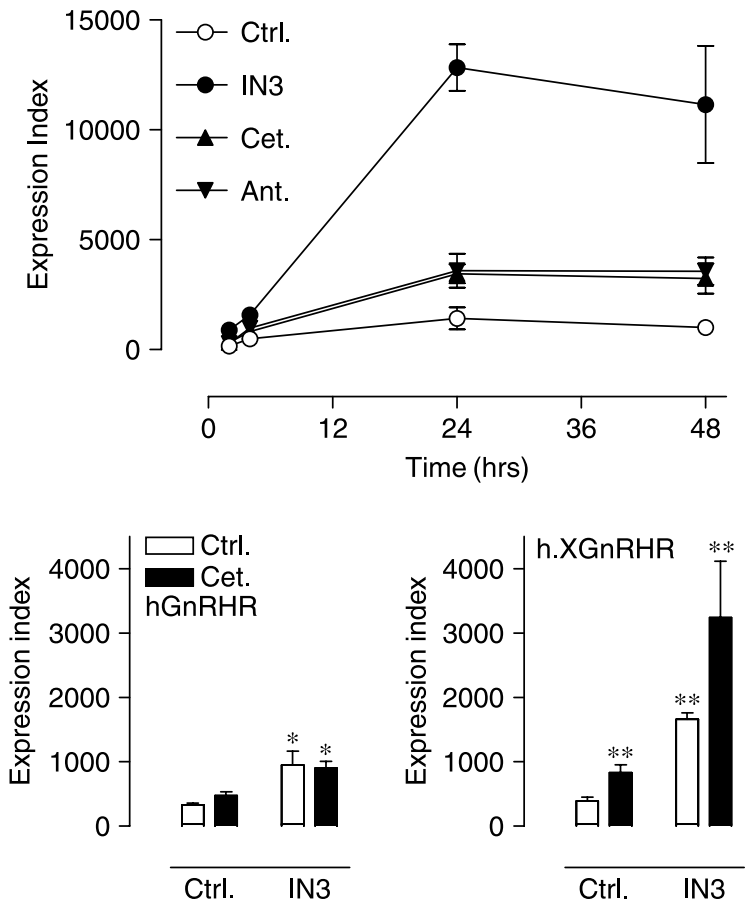

Figure 10 Time course of effects of membrane-permeant and membrane-impermeant ligands on plasma membrane expression of HA-h.XGnRHRs. Upper panel: MCF7 cells were cultured and treated as described under Fig. 9, except that only the HA-h.XGnRHR was used and incubation times were varied as indicated. The data shown are expression indices pooled from four separate experiments each with three replicates (mean \pm S.E.M., $n=4)$. Two-way ANOVA revealed that treatment and time were both significant variables $(P<0 \cdot 01)$ and the effects of all antagonists were significant $(P<0.05$ compared with time-matched controls) at 24 and $48 \mathrm{~h}$. The effects of IN3 (but not cetrorelix or antide) were also significant $(P<0 \cdot 05)$ after 1 and $2 \mathrm{~h}$ of incubation. Lower panels: MCF7 cells were cultured and transduced with Ad HAGnRHR or Ad h.XGnRHR and then incubated 16-24 h with or without IN3 $\left(1.8 \times 10^{-6} \mathrm{M}\right)$ and cetrorelix (cet., $\left.10^{-8} \mathrm{M}\right)$ before staining and imaging. The data shown are pooled from four separate experiments each with three replicates (mean \pm s.E.M., $n=4$ ). Twoway ANOVA revealed IN3 as a significant variable at both receptors and cetrorelix as a significant variable at the HA-h.XGnRHRs $(P<0 \cdot 01)$ but the IN3-cetrorelix interaction was not statistically significant at either receptor $(P>0 \cdot 05) .{ }^{*} P<0 \cdot 05,{ }^{* *} P<0 \cdot 01$ compared with controls by Student's $t$-test.

and $\left.{ }^{3} \mathrm{H}\right] \mathrm{IP}$ accumulation assays with any of the GnRHRs used here (Sedgley et al. 2006, and data not shown).

\section{Effects of IN3 on GnRHR compartmentalization and function}

In exploring functional correlates of IN3 effects on receptor expression, we found that co-incubation with IN3 shifted the concentration-response curve for Buserelin-stimulated $\left[{ }^{3} \mathrm{H}\right] \mathrm{IP}$ accumulation rightward (as expected for a competitive antagonist) but also caused a modest increase in the maximal response (presumably by increasing cell surface receptors). We also constructed concentration-response curves in cells pre- 
treated overnight with IN3 before stimulation with Buserelin in the continued presence of IN3 (Fig. 7), enabling the effect of the pre-treatment to be determined. This revealed profound effects of the chaperone. Thus, for example, $10^{-8} \mathrm{M}$ GnRH increased $\left[{ }^{3} \mathrm{H}\right] \mathrm{IP}$ accumulation by $10 \cdot 6 \%$ when co-incubated with IN3 and by $75 \cdot 7 \%$ when pre- and co-incubated with IN3. Since GnRHR-mediated $\left[{ }^{3} \mathrm{H}\right] \mathrm{IP}$ accumulation responses are often used as measures of receptor number, this sevenfold increase is indicative of a comparable increase in cell surface receptors and supports the idea that the vast majority of potentially functional hGnRHRs are intracellular. In contrast, we found that the IN3 preincubation did not enhance $\left[{ }^{3} \mathrm{H}\right] \mathrm{IP}$ responses mediated by either the h.XGnRHR or the mGnRHR, presumably because these receptors are sufficient at the cell surface to mediate maximal responses, even without IN3. In this regard, we have shown that cell surface h.XGnRHR and mGnRHR are considerably higher than for hGnRHRs (Sedgley et al. 2006) and considerable evidence suggests that the mGnRHR is more efficiently trafficked to the PM than the hGnRHR (Davidson et al. 1996, Janovick et al. 2006). Importantly, these experiments (Fig. 7) were performed with non-tagged GnRHRs and therefore provide a functional correlate with the imaging of HA-GnRHRs herein.

We also tested for effects on cell number as well as on numbers of apoptotic and mitotic cells (Mukherji et al. 2006) and found that Buserelin and IN3 had no effect on cell number in control cells, whereas Buserelin (but not IN3) reduced cell number in cells expressing hGnRHR, h.XGnRHR, or mGnRHR (Fig. 8 and data not shown). Importantly, the effect of Buserelin on cell number was actually increased by IN3 and was paralleled by an increase in the apoptotic index and a reduction in the mitotic index (Fig. 8 and data not shown). Thus, the agonist apparently reduces cell number by reducing proliferation and increasing apoptosis and these effects are enhanced by IN3. Moreover, we found that IN3 increased the hGnRHR-mediated effect on cell number but did not increase the h.XGnRHR- or mGnRHR-mediated effects (not shown), consistent with the $\left[{ }^{3} \mathrm{H}\right] \mathrm{IP}$ accumulation data (Fig. 7D) and the notion that these are sufficient at the surface to mediate maximal effects even without IN3. Thus, this antagonist can actually be used to amplify GnRHR-mediated effects, but only when cell surface receptor number is sufficiently small to be rate limiting for the observed response.

\section{GnRHR compartmentalization in gonadotrope and hormone- dependent cancer cell lines}

We also explored the cell context dependence of GnRHR compartmentalization (Figs 5 and 6) and found that PCSE was low (e.g., $<1 \%$ for the HA-hGnRHR) and the effect of IN3 was pronounced (e.g., HA-hGnRHR PCSE increased 7- to 18-fold by IN3) in two hormone-dependent cancer cell lines (MCF7 and DU145). In contrast, PCSE was considerably higher (e.g., $\sim 5 \%$ for the HA-hGnRHR) and the effect of IN3 was less pronounced (e.g., HA-hGnRHR PCSE increased only 1.5- to 3 -fold by IN3) in L $\beta$ T2 cells. We also considered the possibility that the endogenous mGnRHRs in L $\beta$ T2 cells might increase HA-hGnRHR trafficking to the cell surface, but we have found that expression of untagged $\mathrm{mGnRHRs}$ does not influence the PCSE of co-expressed HA-hGnRHRs (not shown), so these data are unlikely to be influenced by functional interaction between hGnRHRs and mGnRHRs. Thus, these experiments clearly demonstrate that the proportion of hGnRHRs resident at the cell surface of unstimulated cells varies according to the cell type and suggest that cell surface expression may be more efficient in gonadotropes than in hormone-dependent cancer cells.

\section{Effects of peptide and non-peptide antagonists}

Pharmacological chaperones are thought to bind receptors within the ER, holding them in a conformation suitable for ER exit. Key evidence for this includes ER localization of the receptor, dependence of the chaperone effect on ER to Golgi transit, and the inability of peptide ligands to mimic effects of the membrane-permeant pharmacological chaperone (Kopito \& Ron 2000, Bernier et al. 2004). In accord with this, we have shown that HA-hGnRHR is largely co-localized with calreticulin (an ER marker) in MCF7 cells and knockdown of calnexin (a molecular chaperone mediating ER exit of many proteins) can reduce hGnRHR-mediated $\left[{ }^{3} \mathrm{H}\right] \mathrm{IP}$ accumulation and radioligand binding to cell surface hGnRHRs (Brothers et al. 2006). We also compared the effects of IN3, with two peptide antagonists and as expected, IN3 increased the HA-hGnRHR PCSE, whereas the peptides had no such effect. The clear implication is that IN3 increases HA-hGnRHR PCSE by binding nascent receptors within the cell and that the peptides fail to do so because they do not access these intracellular receptors. We also found that these peptide antagonists failed to block the effect of IN3 on HA-hGnRHR PCSE, again arguing that they do not have access to the intracellular site at which IN3 acts. However, we were surprised to find that the peptide antagonists did increase PCSE of HA-h.XGnRHRs. Although their effects were much less than that of IN3 (Fig. 9, lower panel), they were statistically significant. This difference in efficacy was not due to difference in time courses because effects of both IN3 and the peptide antagonists were maximal at 24-48 h of incubation (Fig. 10), or to differences in potency because maximally effective concentrations of these peptides $\left(10^{-7}\right.$ and $\left.10^{-8} \mathrm{M}\right)$ were less effective than IN3 (Figs 9 and 10, data not shown). Moreover, the effects were antagonist specific because $\mathrm{GnRH}$ and Buserelin failed to increase the PCSE of HA-h.XGnRHRs (Fig. 9, data not shown). Theoretically, the GnRHR PCSE could be elevated by increasing ER to PM trafficking, by reducing internalization from the PM, or by accelerating recycling of 
internalized receptors back to the PM. The IN3 effect is largely (or entirely) attributable to the first of these mechanisms; however, since $\mathrm{GnRH}$ analogs are taken up by receptor-mediated endocytosis and do not pass freely across the PM (Scvatrz \& Hazum 1987), and both peptides failed to inhibit IN3 effects on HA-hGnRHR PCSE (Fig. 10), they are unlikely to have access to GnRHRs within the ER. We therefore suggest that the peptide antagonists could act at the cell surface to slow internalization in the face of ongoing trafficking of the HA-h.XGnRHR to and from the PM. This observation has important implications for GnRHR function. Conventional receptor theory assumes that there are single inactive and active receptor conformations that are induced or stabilized by antagonists and agonists respectively. It is now clear, however, that there are multiple active conformations for many 7TM receptors, including GnRHRs (Caunt et al. 2004, Maudsley et al. 2004). The pharmacological chaperone effect of IN3 implies that there are also distinct unoccupied and antagonist-occupied conformations (the unoccupied hGnRHR conformation that fails to exit the ER, and the IN3 occupied conformation that is trafficked to the cell surface). However, conformations within the ER could presumably relate to protein maturation and would not necessarily equate to multiple inactive conformations of the mature receptor at the cell surface. Most importantly, the effect of the peptide antagonists reveals the existence of an antagonist-occupied GnRHR conformation at the cell surface that differs from that of the unoccupied receptor (e.g., that more than one functionally distinct GnRHR conformation can exist at the cell surface that is inactive in terms of PLC activation).

\section{Possible relevance to GnRHR function in hormone-dependent cancers}

In addition to the pituitary, GnRHRs are found in many cancers of reproductive tissues (Cheng \& Leung 2005). GnRH analogs can inhibit proliferation of cell lines derived from such cancers and there is interest in the possibility that direct anti-proliferative effects may contribute to the effects of $\mathrm{GnRH}$ analogs in cancer treatment. However, this field is controversial as, for example, early work revealed direct antiproliferative effects of GnRH agonists and GnRHRs on MCF7 cells, whereas others have observed neither (Everest et al. 2001). This could reflect the use of different sub-clones in different laboratories. Indeed, the MCF7 and DU145 cells used here lack endogenous GnRHRs as judged by radioligand binding, $\left[{ }^{3} \mathrm{H}\right] \mathrm{IP}$ accumulation, and $\left[{ }^{3} \mathrm{H}\right]$ thymidine incorporation assays (Everest et al. 2001, Franklin et al. 2003). Where found, the GnRHRs of hormone-dependent cancers are often of lower affinity (Eidne et al. 1987, Emons et al. 1998, Schally 1999, Cheng \& Leung 2005) and may signal differently to those in the pituitary. Typically, they fail to elicit the PLC activation characteristic of pituitary GnRHRs (Emons et al. 1998,
Schally 1999, Cheng \& Leung 2005) and the established agonist/antagonist dichotomy may not be retained in cancer cells, where compounds that act as antagonists at gonadotrope GnRHRs can actually mimic agonist effects (Emons et al. 1998, Schally 1999, Cheng \& Leung 2005). Such differences occur in spite of the fact that the type I GnRHR transcripts in breast and ovarian cancers are identical to those of the pituitary (Kakar et al. 1994) and do not reflect activation of type II GnRHR because a missense mutation and premature stop codon prevent full length GnRHR expression from the human type II GnRHR (pseudo)gene (Millar 2005). Our data raise the possibility that compartmentalization may underlie some of these differences. Thus, binding protocols using crude PM preparations (and developed largely for work with rodent tissues and cells) may be inappropriate for detection of hGnRHRs that are primarily intracellular in cancer cells. Similarly, effects on rapid responses such as $\mathrm{Ca}^{2+}$ mobilization and $\left[{ }^{3} \mathrm{H}\right] \mathrm{IP}$ accumulation may be more readily detected when a large proportion of GnRHRs are PM resident (favoring detection of responses mediated by rodent receptors in gonadotropes), whereas chronic effects on proliferation may provide time for intracellular receptors to traffic to the surface for signaling (favoring detection of responses mediated by hGnRHRs in cancer cells). Similarly, the existence of functionally distinct peptide antagonistoccupied and antagonist-unoccupied GnRHR conformations is compatible with peptide antagonist signaling in cancer cells. Although these issues are speculative, we suggest that the low PCSE and existence of a large intracellular reserve of potentially functional hGnRHRs may be important for understanding of GnRHR signaling in hormone-dependent cancer cells.

\section{Agonist-induced receptor trafficking}

A further surprising observation was that GnRH did not reduce the PCSE for hGnRHRs or h.XGnRHRs (Fig. 9) because agonist-induced GnRHR internalization and the consequent reduction in PM receptors are assumed to contribute toward desensitization of $\mathrm{GnRH}$-stimulated gonadotropin secretion (Conn \& Crowley 1994). However, we have shown that equilibrium binding of $\left[{ }^{125} \mathrm{I}\right]$ Buserelin to cell surface hGnRHRs in MCF7 cells is extremely low and that binding can be rapidly increased by raising the temperature to $37^{\circ} \mathrm{C}$, suggesting the existence of cryptic receptors that can move to the cell surface at temperatures permissive for trafficking (Sedgley et al. 2006). Since no such temperature-dependent increase was seen with hGnRHRs mutated to prevent G-protein-mediated signaling, we suggested that the cell surface GnRHR activation may stimulate recruitment from the cryptic receptor pool in this model. Thus, the lack of GnRH effect on PCSE (Fig. 9) could reflect concomitant agonist-induced recruitment to and internalization from the PM. It is important to recognize, however, that most of the early work on agonist-induced 
GnRHR internalization was undertaken with rodent GnRHRs (Jennes et al. 1986, Conn et al. 1987, McArdle et al. 1987, Schvartz \& Hazum 1987, Hazum \& Conn 1988) which are now thought to be trafficked to the PM more efficiently than hGnRHRs (Janovick et al. 2003, Ulloa-Aguirre et al. 2004). Moreover, one of the key arguments for the occurrence of agonist-induced GnRHR internalization is that internalization is faster for labeled agonists than for labeled antagonists but the effect of antide and cetrorelix on PCSE raises the possibility that these antagonists could actually slow hGnRHR internalization. As such, our observations highlight the need for more direct assessment of agonist effects on internalization of hGnRHRs in gonadotrope and extrapituitary cell types.

In summary, we have developed a rapid and efficient means of measuring GnRHR expression at the cell surface and within cells and have used this to calculate, for the first time, the proportion of GnRHRs at the cell surface in hormonedependent cancer cells and in gonadotrope lineage cells. We show that the proportion of HA-hGnRHRs at the cell surface of MCF7 breast cancer cells is remarkably low $(<1 \%)$ when compared with the XGnRHR $(\sim 40 \%)$ even at comparable whole cell expression levels, and that the PCSE of the HA-hGnRHR can be increased by addition of the XGnRHR C-tail and by stimulation with non-peptide antagonists IN3. The IN3 effect is concentration- and timedependent and IN3 pretreatment increased expression of functional hGnRHRs at the cell surface, as revealed by its ability to increase hGnRHR-mediated (but not h.XGnRHR- or mGnRHR-mediated) $\left[{ }^{3} \mathrm{H}\right] \mathrm{IPx}$ accumulation and effects on cell number. In all of these experiments, effects on cell surface GnRHR expression were paralleled by changes in proportion of GnRHRs at the cell surface, underlining the importance of compartmentalization as a determinant of cell surface GnRHR number. Exploring context dependence, we found that the proportion of hGnRHRs and h.XGnRHRs at the cell surface is low and is greatly increased by IN3 in two hormone-dependent (breast- and prostate-derived) cancer lines but is considerably higher and less sensitive to IN3 in a gonadotrope line. Finally, we show that in MCF7 cells, the proportion of h.XGnRHRs at the cell surface can also be increased by two (membrane impermeant) peptide antagonists. This unexpected observation reveals the existence of an antagonist-occupied conformation of a cell surface GnRHR that is functionally distinct from that of the unoccupied receptor. The low proportion of hGnRHRs at the cell surface and this novel antagonist effect on cell surface receptor conformation and number may be important parameters in understanding GnRHR function in extrapituitary sites. Indeed, much of the recent work on GnRHR trafficking has focused on the potential use of pharmacological chaperones to rescue trafficking deficient hGnRHR point mutants, whereas our data highlight the potential for peptide and non-peptide antagonists to influence cell surface expression of wild-type hGnRHRs in hormone-dependent cancers.

\section{Acknowledgements}

We are grateful to Prof. P Mellon (UCSD, CA, USA), Prof. R Millar (Medical Research Council Human Reproductive Sciences Unit, Edinburgh, UK), and to Dr Ashton Wallace (Merck and Co. Inc.) for materials. This work was supported by the Wellcome Trust (Project Grant awards 062918, and 076557 and Equipment Grant 078407, to CAM). The authors declare that there is no conflict of interest that would prejudice the impartiality of this scientific work.

\section{References}

Bernier V, Bichet DG \& Bouvier M 2004 Pharmacological chaperone action on G-protein-coupled receptors. Current Opinion in Pharmacology 4 528-533.

Blomenrohr M, Heding A, Sellar R, Leurs R, Bogerd J, Eidne KA \& Willars GB 1999 Pivotal role for the cytoplasmic carboxyl-terminal tail of a nonmammalian gonadotropin-releasing hormone receptor in cell surface expression, ligand binding, and receptor phosphorylation and internalization. Molecular Pharmacology 56 1229-1237.

Brothers SP, Cornea A, Janovick JA \& Conn PM 2004 Human lossof-function gonadotropin-releasing hormone receptor mutants retain wildtype receptors in the endoplasmic reticulum: molecular basis of the dominant-negative effect. Molecular Endocrinology 18 1787-1797.

Brothers SP, Janovick JA \& Conn PM 2006 Calnexin regulates gonadotropinreleasing hormone receptor plasma membrane expression. Journal of Molecular Endocrinology 37 479-488.

Caunt CJ, Hislop JN, Kelly E, Matharu AL, Green LD, Sedgley KR, Finch AR \& McArdle CA 2004 Regulation of gonadotropin-releasing hormone receptors by protein kinase $\mathrm{C}$ : inside out signalling and evidence for multiple active conformations. Endocrinology 145 3594-3602.

Caunt CJ, Finch AR, Sedgley KR, Oakely L, Luttrell LM \& McArdle CA 2006 Arrestin-mediated ERK activation by gonadotropin-releasing hormone receptors: receptor-specific activation mechanisms and compartmentalization. Journal of Biological Chemistry 281 2701-2710.

Cheng CK \& Leung PCK 2005 Molecular biology of gonadotropin-releasing hormone (GnRH)-I, GnRH-1I, and their receptors in humans. Endocrine Reviews 26 283-306.

Conn PM \& Crowley WF, Jr 1994 Gonadotropin-releasing hormone and its analogs. Annual Review of Medicine 45 391-405.

Conn PM, Huckle WR, Andrews WV \& McArdle CA 1987 The molecular mechanism of action of gonadotropin releasing hormone $(\mathrm{GnRH})$ in the pituitary. Recent Progress in Hormone Research 43 29-61.

Davidson JS, Flanagan CA, Zhou W, Becker El, II, Elario R, Emeran W, Sealfon SC \& Millar RP 1995 Identification of $N$-glycosylation sites in the gonadotropin-releasing hormone receptor: role in receptor expression but not ligand binding. Molecular and Cellular Endocrinology 107 241-245.

Davidson JS, Flanagan CA, Davies PD, Hapgood J, Myburgh D, Elario R, Millar RP, ForrestOwen W \& McArdle CA 1996 Incorporation of an additional glycosylation site enhances expression of functional human gonadotropin-releasing hormone receptor. Endocrine 4 207-212.

Eidne KA, Flanagan CA, Harris NS \& Millar RP 1987 Gonadotropinreleasing-hormone $(\mathrm{GnRH})$-binding sites in human-breast cancer cell-lines and inhibitory effects of GnRH antagonists. Journal of Clinical Endocrinology and Metabolism 64 425-432.

Emons G, Muller V, Ortmann O \& Schulz KD 1998 Effects of LHRHanalogues on mitogenic signal transduction in cancer cells. Journal of Steroid Biochemistry and Molecular Biology 65 199-206.

Everest HM, Hislop JN, Harding T, Uney JB, Flynn A, Millar RP \& McArdle CA 2001 Signaling and antiproliferative effects mediated by GnRH receptors after expression in breast cancer cells using recombinant adenovirus. Endocrinology 142 4663-4672. 
Finch AR, Green L, Hislop JN, Kelly E \& McArdle CA 2004 Signaling and antiproliferative effects of type I and II gonadotropin-releasing hormone receptors in breast cancer cells. Journal of Clinical Endocrinology and Metabolism 89 1823-1832.

Franklin J, Hislop J, Flynn A \& McArdle CA 2003 Signalling and antiproliferative effects mediated by gonadotropin-releasing hormone receptors after expression in prostate cancer cells using recombinant adenovirus. Journal of Endocrinology 176 275-284.

Hazum E \& Conn PM 1988 Molecular mechanism of gonadotropin releasing hormone (GnRH) action. I. The GnRH receptor. Endocrine Reviews 9 379-386.

Hislop JN, Everest HM, Flynn A, Harding T, Uney JB, Troskie BE, Millar RP \& McArdle CA 2001 Differential internalization of mammalian and nonmammalian gonadotropin-releasing hormone receptors. Uncoupling of dynamin-dependent internalization from mitogen-activated protein kinase signaling. Journal of Biological Chemistry 276 39685-39694.

Hislop JN, Caunt CJ, Sedgley KR, Kelly E, Mundell S, Green LD \& McArdle CA 2005 Internalization of gonadotropin-releasing hormone receptors (GnRHRs): does arrestin binding to the C-terminal tail target GnRHRs for dynamin-dependent internalization? Journal of Molecular Endocrinology 35177.

Imai A, Horibe S, Takagi A \& Tamaya T 1997 Gi protein activation of gonadotropin-releasing hormone-mediated protein dephosphorylation in human endometrial carcinoma. American Journal of Obstetrics and Gynecology 176 371-376.

Janovick JA, Maya-Nunez G \& Conn PM 2002 Rescue of hypogonadotropic hypogonadism-causing and manufactured $\mathrm{GnRH}$ receptor mutants by a specific protein-folding template: misrouted proteins as a novel disease etiology and therapeutic target. Journal of Clinical Endocrinology and Metabolism 87 3255-3262.

Janovick JA, Ulloa-Aguirre A \& Conn PM 2003 Evolved regulation of gonadotropin-releasing hormone receptor cell surface expression. Endocrine 22 317-327.

Janovick JA, Knollman PE, Brothers SP, yala-Yanez R, Aziz AS \& Conn PM 2006 Regulation of $\mathrm{G}$ protein-coupled receptor trafficking by inefficient plasma membrane expression: molecular basis of an evolved strategy. Journal of Biological Chemistry 281 8417-8425.

Jennes L, Coy D \& Conn PM 1986 Receptor-mediated uptake of GnRH agonist and antagonists by cultured gonadotropes: evidence for differential intracellular routing. Peptides 7 459-463.

Kakar SS, Grizzle WE \& Neill JD 1994 The nucleotide sequences of human GnRH receptors in breast and ovarian tumors are identical with that found in pituitary. Molecular and Cellular Endocrinology 106 145-149.

Knollman PE, Janovick JA, Brothers SP \& Conn PM 2005 Parallel regulation of membrane trafficking and dominant-negative effects by misrouted gonadotropin-releasing hormone receptor mutants. Journal of Biological Chemistry $28024506-24514$.

Kopito RR \& Ron D 2000 Conformational disease. Nature Cell Biology 2 E207-E209.

Limonta P, Moretti RM, Marelli MM \& Motta M 2003 The biology of gonadotropin hormone-releasing hormone: role in the control of tumor growth and progression in humans. Frontiers in Neuroendocrinology 24 279-295.

Lin X, Janovick JA, Brothers S, Blomenrohr M, Bogerd J \& Conn PM 1998 Addition of catfish gonadotropin-releasing hormone $(\mathrm{GnRH})$ receptor intracellular carboxyl-terminal tail to rat $\mathrm{GnRH}$ receptor alters receptor expression and regulation. Molecular Endocrinology 12 161-171.

Maudsley S, Davidson L, Pawson AJ, Chan R, Lopez de MR \& Millar RP 2004 Gonadotropin-releasing hormone $(\mathrm{GnRH})$ antagonists promote proapoptotic signaling in peripheral reproductive tumor cells by activating a Galphai-coupling state of the type I GnRH receptor. Cancer Research 647533.

McArdle CA, Gorospe WC, Huckle WR \& Conn PM 1987 Homologous down-regulation of gonadotropin-releasing-hormone receptors and desensitization of gonadotropes - lack of dependence on protein-kinase-C. Molecular Endocrinology 1 420-429.

McArdle CA, Schomerus E, Groener I \& Poch A 1992 Estradiol regulates gonadotropin-releasing hormone receptor number, growth and inositol phosphate production in alphaT3-1 cells. Molecular and Cellular Endocrinology 87 95-103.

McArdle CA, Franklin J, Green L \& Hislop JN 2002 Signalling, cycling and desensitization of gonadotropin-releasing hormone receptors. Journal of Endocrinology 173 1-11.

Millar RP 2005 GnRHs and GnRH receptors. Animal Reproduction Science $\mathbf{8 8}$ $5-28$.

Millar RP, Lu ZL, Pawson AJ, Flanagan CA, Morgan K \& Maudsley SR 2004 Gonadotropin-releasing hormone receptors. Endocrine Reviews 25 235-275.

Moretti RM, Marelli MM, van Groeninghen JC, Motta M \& Limonta P 2003 Inhibitory activity of luteinizing hormone-releasing hormone on tumor growth and progression. Endocrine-Related Cancer 10 161-167.

Mukherji M, Bell R, Supekova L, Wang Y, Orth AP, Batalov S, Miraglia L, Huesken D, Lange J, Martin C et al. 2006 Genome-wide functional analysis of human cell-cycle regulators. PNAS 103 14819-14824.

Pawson AJ, Katz A, Sun YM, Lopes J, Illing N, Millar RP \& Davidson JS 1998 Contrasting internalization kinetics of human and chicken gonadotropinreleasing hormone receptors mediated by C-terminal tail. Journal of Endocrinology 156 R9-R12.

Petaja-Repo UE, Hogue M, Bhalla S, Laperriere A, Morello JP \& Bouvier M 2002 Ligands act as pharmacological chaperones and increase the efficiency of delta opioid receptor maturation. EMBO Journal 21 1628-1637.

Schally AV 1999 LH-RH analogues: their impact on human reproduction and the control of tumorigenesis. Peptides 20 1247-1262.

Schally AV \& Nagy A 1999 Cancer chemotherapy based on targeting of cytotoxic peptide conjugates to their receptors on tumors. European Journal of Endocrinology 141 1-14.

Schvartz I \& Hazum E 1987 Internalization and recycling of receptor-bound gonadotropin-releasing hormone agonist in pituitary gonadotropes. Journal of Biological Chemistry 262 17046-17050.

Sedgley KR, Finch AR, Caunt CJ \& McArdle CA 2006 Intracellular gonadotropin-releasing hormone receptors in breast cancer and gonadotrope lineage cells. Journal of Endocrinology 191 625-63612.

Stojilkovic SS \& Catt KJ 1995 Expression and signal transduction pathways of gonadotropin-releasing hormone receptors. Recent Progress in Hormone Research 50 161-205.

Ulloa-Aguirre A, Janovick JA, Brothers SP \& Conn PM 2004 Pharmacologic rescue of conformationally-defective proteins: implications for the treatment of human disease. Traffic 5821 .

\section{Received in final form 31 October 2007 Accepted 6 November 2007 Made available online as an Accepted Preprint 6 November 2007}

